ISSN 1392-1541

Geodezija ir kartografija, 2005, XXIX t., Nr. 3

Geodesy and Cartography, 2005, Vol XXIX, No 3

UDK 528.422

\title{
SKAITMENINIŲ RELJEFO MODELIŲ, SUDARYTŲ TAIKANT IVAIRIUS PRADINIUS DUOMENIS, TIKSLUMO TYRIMAS
}

\author{
Aušra Kumetaitienè \\ Vilniaus Gedimino technikos universitetas, Geodezijos ir kadastro katedra, \\ Saulètekio al. 11, LT-10223 Vilnius-40, Lietuva, el. paštas: a.kumetaitienė@ivpk.lt
}

Iteikta 200503 29, priimta 20050707

\begin{abstract}
Santrauka. Analizuojamas pradinių duomenų, turinčiu tiesioginès įtakos sudaromo skaitmeninio reljefo modelio (toliau SRM) kokybei, tikslumas, padètis ir tankis. Svarbu gauti kokybiškus aukščiu duomenis, kurie atitiktų reljefo modeliui keliamus reikalavimus. Tašku skaičius turi būti pakankamai tankus, kad aukščių taškų pakaktų ne tik reljefo modeliui sudaryti, bet ir tikslumo kontrolei atlikti. Duomenu kokybinès ir kiekybinès charakteristikos bei ekonominiai rodikliai priklauso nuo pasirinkto aukščių matavimų metodo. Atliktas tyrimas, siekiant ịvertinti pradinių duomenų, skirtų skaitmeniniam reljefo modeliui sudaryti, tikslumą.
\end{abstract}

Raktažodžiai: skaitmeninis reljefo modelis, tikslumas, InSAR metodas, automatinis stereofotogrametrinis metodas, stereofotogrametrinis metodas

\section{Ivadas}

Dabar pasaulyje plačiai naudojami iš vektorizuotų horizontaliu sudaryti skaitmeniniai reljefo modeliai (SRM). Šių modelių populiarumą lemia analoginių žemėlapių gausa. Iš jų vektorizuojamos horizontalès. Lauko matavimai skaitmeniniams reljefo modeliams sudaryti netaikomi, nes yra per brangūs. Jie taikomi tik SRM kontrolei. Vis reikšmingesnis tampa SRM sudarymas distanciniais matavimų metodais. Šie matavimai skirstomi i tiesioginius (LiDAR, InSAR) ir fotogrametrinius. Modeliavimo metodais, netaikant horizontaliu, pasiekiama geresnè SRM kokybè. Naujai taikomos tiesioginio žemès paviršiaus matavimo technologijos leidžia reljefo modelyje sumažinti klaidų [1]. Lazerinès altimetrijos, kitaip LiDAR (angl. Light distance and ranging), matavimų metodikos tobulinimas sudaro prielaidas ateityje gauti didelès skiriamosios gebos ir tikslumo SRM [2-4], panašiai kaip jūros dugno batimetrija [5]. Radarinès interferometrijos (InSAR arba $I d S A R$ ) metodas reljefo matavimo tikslumu ir didele skiriamaja geba gali konkuruoti su optiniais reljefo matavimais $[6,7]$. Interferometrija taikoma ir topografiniams poslinkiams fiksuoti, pavyzdžiui, geologinių sprūdžių teritorijose. LiDAR lèktuvuose montuojama lazerinè matavimų sistema atlieka 2000-5000 aukščio matavimų per sekundę $\pm 15 \mathrm{~cm}$ tikslumu. Iš šių gausių paviršiaus matavimų duomenų gali būti sudaromi didelès teritorijos $1 \mathrm{~m}$ skiriamosios gebos SRM [8]. Matavimu šiuo metodu sąnaudos panašios i fotogrametrinio metodo arba horizontaliu vektorizavimo, o duomenų apdorojimas ir koregavimas (augmenijos ir antropogeninių objektų pašalinimas iš reljefo modelio) atsieina mažiau. Šis metodas efektyvus ir konkurencingas. LiDAR metodas taip pat gali būti taikomas kartu su skaitmenine fotogrametrija tiksliems nedidelių teritorijų reljefo modeliams sudaryti.

Ir tiesioginiai, ir fotogrametriniai matavimai turi tą pati trūkumą: iš oro ne visada matomas žemès paviršius, todèl šiose vietose paviršiaus tiksliai išmatuoti neįmanoma.

Tyrimų objektu pasirinkta Lietuva, nes šioje teritorijoje SRM sudaryti taikant visus minètuosius metodus, o straipsnio autore atliko papildomus stereofotogrametrinius matavimus Vilniaus teritorijoje. Sudaryti keli skaitmeniniai Lietuvos teritorijos vietovès modeliai (1 lentelè). Jie skiriasi tikslumu, detalumu, paviršiaus skiriamaja geba, panaudotais pradiniais duomenimis.

1 lentelè. Lietuvos teritorijos skaitmeniniai vietovès modeliai Table 1. The digital terrain models of Lithuania

\begin{tabular}{|c|c|c|l|}
\hline $\begin{array}{c}\text { Reljefo } \\
\text { modelis }\end{array}$ & $\begin{array}{c}\text { Duomenu } \\
\text { paruošimo } \\
\text { metodas }\end{array}$ & $\begin{array}{c}\text { Lastelès } \\
\text { dydis }\end{array}$ & Duomenu šaltinis \\
\hline Lietuvos & InSAR metodas & $50 \times 50 \mathrm{~m}$ & $\begin{array}{l}\text { distanciniai } \\
\text { matavimai }\end{array}$ \\
\hline Lietuvos & $\begin{array}{c}\text { Anudem } \\
\text { metodas: } \\
\text { horizontaliu } \\
\text { interpoliavimas }\end{array}$ & $50 \times 50 \mathrm{~m}$ & $\begin{array}{l}1942 \mathrm{~m} \text {. koordinačiu } \\
\text { sistemos žemèlapiu } \\
\text { horizontalès }\end{array}$ \\
\hline $\begin{array}{c}\text { Kauno, } \\
\text { Klaipėdos }\end{array}$ & $\begin{array}{c}\text { automatinis } \\
\text { stereofoto- } \\
\text { grametrinis }\end{array}$ & $2 \times 2 \mathrm{~m}$ & $\begin{array}{l}\text { fotogrametriniai } \\
\text { matavimai }\end{array}$ \\
\hline Vilniaus & $\begin{array}{c}\text { stereofoto- } \\
\text { grametrinis }\end{array}$ & $2 \times 2 \mathrm{~m}$ & $\begin{array}{l}\text { stereofoto- } \\
\text { grametrinis } \\
\text { digitalizavimas }\end{array}$ \\
\hline
\end{tabular}




\section{Reljefo modelio, sudaryto InSAR metodu, tikslumo ivertinimas}

Kosminio vaizdo $50 \mathrm{~m}$ skiriamosios gebos skaitmeninis vietovès modelis buvo sudarytas InSAR metodu pagal NASA programą. Šiuo metodu buvo išmatuotas visos Europos sausumos paviršius. InSAR metodas leidžia tiksliai išmatuoti lygaus arba nelabai kalvoto paviršiaus aukščių taškus. Tose vietose, kur žemès paviršiuje yra augmenija, išmatuojamas iš dalies ir augmenijos dengiamas paviršius, žemès paviršius, priklausomai nuo augmenijos tankumo. Vietovèse, kur dideli nuolydžiai, matavimai InSAR metodu ne visada imanomi.

Straipsnio autorès atlikta SRM analizè parodè, kad šis modelis turi daug trūkumų, lemiamų paviršiaus matavimų metodo.

Pastebėta, kad sudarant skaitmenini reljefo modeli InSAR metodu, lieka neišmatuota nemažai pavienių plotų giliuose upių slëniuose (1 pav.).

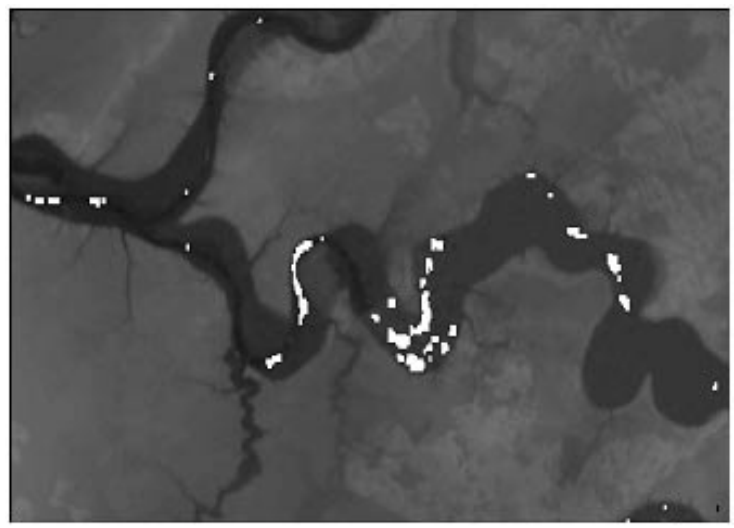

1 pav. Nemuno ir Neries santakos SRM fragmentas, sudarytas InSAR metodu

Fig 1. DTM fragment of Nemunas and Neris confluence, created using InSAR method

Neišmatuota liko $53,56 \mathrm{~km}^{2}$ Lietuvos teritorijos. Šių vietovių paviršiaus duomenys gali būti gauti interpoliuojant esamus arba naudojant papildomus aukščiu taškus. Atlikus skaitmeninio reljefo modelio, sudaryto InSAR metodu, analizę, lyginant su SRM, sudarytu netaisyklingu trikampių tinklą pavertus stačiakampiu rastru (Vilnius99), paaiškejjo, kad šis skaitmeninis paviršiaus modelis yra nelabai detalus, neatspindi smulkių reljefo detalių (2 pav. 1 ir 2 elipse pažymètos profilio atkarpos).

Smulkūs reljefo nelygumai, matomi sudarant paviršiaus modelị iš horizontalių arba aukščio taškų, dažniausiai neišmatuojami. Taip pat dažnai praleidžiami reljefo i̇dubimai, vietomis reljefo modelyje matomi tikrovejje neegzistuojantys paviršiaus nelygumai ( 2 pav. 3 apskritimu pažymėta profilio atkarpa). Autorès nuomone, šie netikslumai galejo atsirasti dẻl netikslių matavimu staigių paviršiaus pokyčių vietose. Kreivẻ grafiko (2 pav.) apačioje žymi zonų, per kurias eina reljefo profilis, numerius. Kuo trumpesnè atkarpa, tuo mažesni plotą užima nurodyta zona.

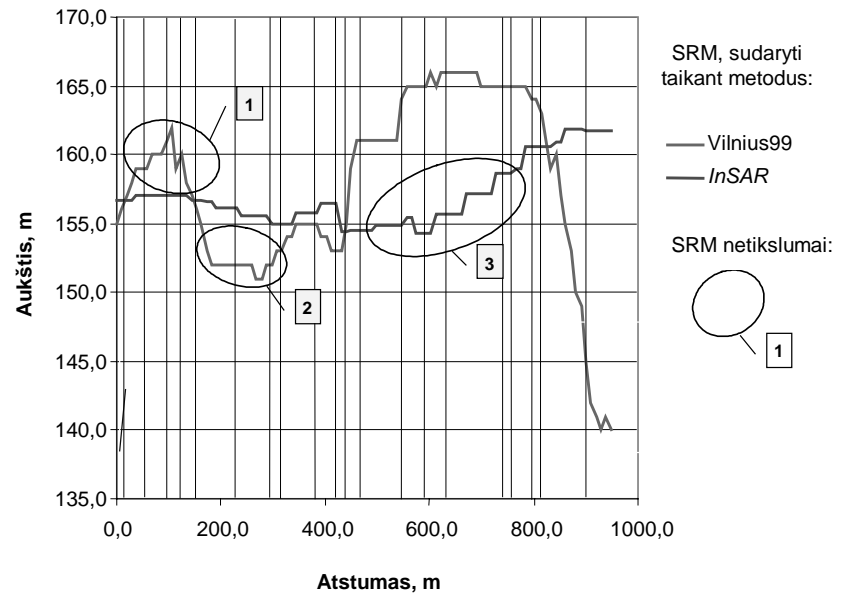

2 pav. SRM, sudaryto InSAR metodu, analizè

Fig 2. DTM, created using InSAR method analysis

Palyginus InSAR metodu sudarytą SRM su Vilniaus teritorijoje fotogrametriškai išmatuotomis tašku altitudemis, standartinis nuokrypis $\sigma=4,57 \mathrm{~m}$ (2 lentelè).

2 lentelè. Skaitmeninio reljefo modelio tikslumo duomenys

Table 2. Accuracy data of DTM

\begin{tabular}{|l|c|}
\hline SRM statistiniai duomenys & $\begin{array}{c}50 \mathrm{~m} / \\
\text { InSAR }\end{array}$ \\
\hline Kontrolinių taškų kiekis, vnt. & 3115 \\
\hline Vidutinis altitudžių skirtumas $\Delta h, \mathrm{~m}$ & 2,26 \\
\hline Standartinio nuokrypio įvertis $\sigma, \mathrm{m}$ & 4,57 \\
\hline Didžiausias altitudžių skirtumas $\Delta h_{\max }, \mathrm{m}$ & 25,17 \\
\hline
\end{tabular}

\section{Reljefo modelio, sudaryto digitalizuojant horizon-} tales, tikslumo analizè

Lietuvos teritorijos $50 \mathrm{~m}$ skiriamosios gebos skaitmeninis reljefo modelis (DEM50) sudarytas Anudem metodu iš horizontalių, kaip papildomą informaciją paviršiui modeliuoti naudojant aukščiu taškus bei linijinius hidrografijos duomenis. Aukščiu duomenims interpoliuoti taikyta krigingo metodas. DEM50 yra stačiakampiu tinklo reljefo modelis. Tinklini modeli sudaro ląstelių masyvas iš 5985 eilučių ir 7775 stulpelių, iš viso 46533375 ląstelès. DEM50 nėra tikslus dèl kelių faktorių [9]:

- nèra visiškai patikimu pradinių duomenų SRM sudaryti;

- paviršiaus modeliavimo metodo lemti trūkumai.

Iki šiol kartografinès medžiagos leidybai naudojamos $1942 \mathrm{~m}$. koordinačių sistemoje nubraižytos horizontalès. Palyginus geodezinio pagrindo aukščių taškus bei stereodigitalizuotus aukščiu taškus paaiškejjo, kad vietomis horizontalių duomenys nepatikimi.

Paviršiaus profilio analizè parodè, $\mathrm{kad}$ iš horizontalių sudarytas SRM neatspindi nedidelių reljefo pokyčių. Vidutiniai reljefo pokyčiai taip pat nėra detaliai atvaizduojami. Tai gali būti dèl horizontalių braižymo netikslumų arba dèl pasenusių reljefo duomenų. Kitą skaitmeninio reljefo modelio trūkumą lemia paviršiaus formavimo metodas. Paviršius, suformuotas iš 


\section{Ląsteliu skaičius (tūkst.)}

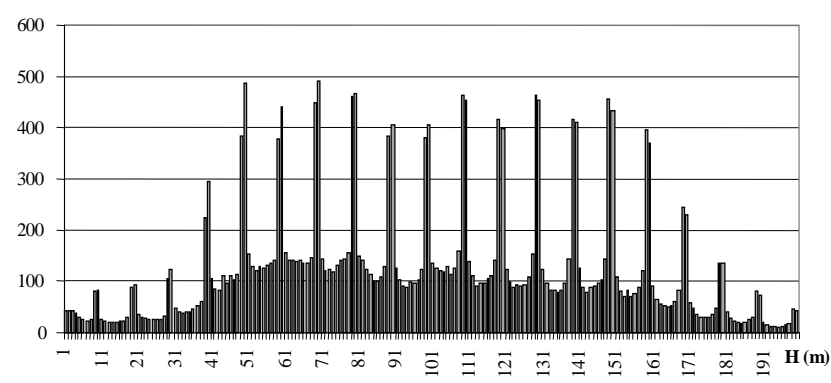

3 pav. Skaitmeninio reljefo modelio, sudaryto iš horizontaliu, histograma

Fig 3. Histogram of digital terrain model, created from height contour lines

horizontalių, esti laiptuotas. Tai matyti iš SRM paviršiaus reikšmių histogramos (3 pav.).

Modeliuojant reljefą, būtina atsižvelgti i hidrografijos objektų kranto liniją, priešingu atveju vandens telkinių paviršius gaunamas „banguotas“. Tai labai gerai matoma Kuršių marių ir Baltijos jūros teritorijose.

Toki paviršių galima pataisyti, šių objektų kranto liniją panaudojant kaip horizontalę, pagal kurią koreguojamas ir ,išlyginamas“ vandens telkinių paviršius. Didžiausi altitudžių skirtumai $(\geq 5 \mathrm{~m})$ šiame reljefo modelyje kaupiasi tose vietose, kuriose dideli reljefo nuolydžiai (3 lentelè). Tai būdinga ir miškingoms raižyto reljefo vietovèms.

3 lentelè. Statistiniai reljefo modelių altitudžių skirtumų parametrai

Table 3. Statistical parameters of DTM height differences

\begin{tabular}{|l|c|c|}
\hline $\begin{array}{l}1996 \text { m. SRM statistiniai } \\
\text { duomenys }\end{array}$ & $\begin{array}{c}\text { Lietuvos } \\
\text { teritorijoje }\end{array}$ & $\begin{array}{c}\text { Šeškinès } \\
\text { ozo } \\
\text { teritorijoje } \\
\text { Vilniuje }\end{array}$ \\
\hline $\begin{array}{l}\text { Kontrolinių taškų skaičius, } \\
\text { vnt. }\end{array}$ & 64451 & 3115 \\
\hline $\begin{array}{l}\text { Vidutinis altitudžių } \\
\text { skirtumas } \Delta h, \mathrm{~m}\end{array}$ & $-0,8$ & $-0,71$ \\
\hline $\begin{array}{l}\text { Standartinio nuokrypio } \\
\text { ivertis } \sigma, \mathrm{m}\end{array}$ & 3,0 & 3,92 \\
\hline $\begin{array}{l}\text { Didžiausias altitudžių } \\
\text { skirtumas } \Delta h_{\max }, \mathrm{m}\end{array}$ & 29,0 & 18,15 \\
\hline
\end{tabular}

Atsižvelgiant i Lietuvos teritorijos reljefo pobūdị, tikslintina teritorija laikytini didžiųų upių slëniai stačiais šlaitais. Skaitmeninis reljefo modelis tikslinamas naudojant hidrografijos taškus.

\section{Automatizuotai sudaryto reljefo modelio tikslumo analizè}

Ortofotografinio žemėlapio sudarymas susideda iš šių etapų: aeronuotraukų skenavimo, skaitmeninès aerotrianguliacijos, SRM sudarymo, ortofotografinio žemėlapio sudarymo bei koregavimo pagal sudarytą SRM [10]. Vienas iš būtinų ortofotografinių žemèlapių gamybos proceso etapu yra SRM sudarymas automatiniu stereofotogrametriniu metodu. Šiuo metodu reljefas modeliuojamas naudojant sutampančias aerofotonuotraukas. Teorinis šiuo metodu sudaryto SRM aukščio tikslumas yra 0,3-1 ląstelès dydžio, t. y. $0,1 \%$ o Hs - 0,2\%o Hs (Hs - skrydžio aukštis) atviroje vietoveje ir $1 \%$ Hs $2 \%$ o Hs miškingoje teritorijoje [11].

Aerogeodezijos institute automatiniu stereofotogrametriniu metodu, naudojant Leica darbo stoti, sudarytas Kauno $2 \times 2 \mathrm{~m}$ ląstelès dydžio skaitmeninis paviršiaus modelis. Šis metodas labai perspektyvus, nes ortofotografiniai šalies žemėlapiai nuolat atnaujinami, o SRM gali būti gaunamas ortofotografini žemèlapi gaminant - kaip papildomas produktas, kuriam nereikia atskiros aeronuotraukos. Todèl šis metodas gali būti taikomas norint greitai sudaryti didelès teritorijos skaitmenini reljefo modelį.

Taip gautas modelis apima ne tik žemès paviršių, bet ir antžeminius objektus, iškilusius aukščiau žemės paviršiaus: pastatus, miškus, pavienius medžius, krūmynus (4 pav.).

Palyginę skaitmeninio reljefo modelio, gauto automatiniu stereofotogrametriniu metodu (Kauno SRM) ir SRM, sudaryto Anudem metodu iš horizontalių, skerspjūvio profilius, matome, kad automatiniu stereofotogrametriniu metodu sudarytas paviršiaus modelis yra labai detalus ir atspindi smulkius paviršiaus nelygumus.

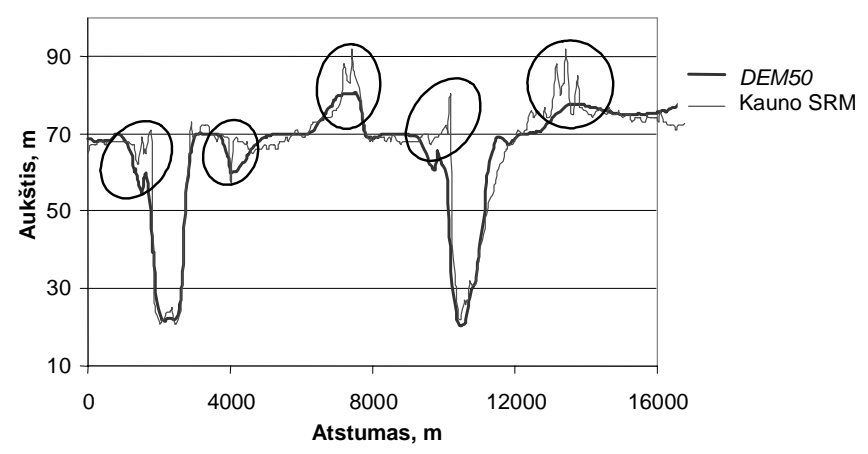

4 pav. Antžeminiai objektai, atsispindintys Kauno SRM

Fig 4. Above-ground objects reflecting on Kaunas DEM

Nagrinëjamas profilis išvestas per Nemuno ir Neries upių slènius Kauno teritorijoje. Matome, kad hidrografijos ir kitiems antžeminiams reiškiniams (pavyzdžiui, dirvos erozijai) modeliuoti toks paviršius netinka, nes apima daug antžeminių objektų (4 pav. apskritimais apibrèžtos profilio atkarpos), kurie iškraipo tikraji žemès paviršiaus vaizdą. Norint iš šio SRM sukurti skaitmenini reljefo modelị, prieš tai reikia pašalinti antžeminius objektus. Tai gali būti atliekama rankiniu būdu, naudojant papildomą aukščių informaciją tų vietų, kuriose dideli paviršiaus plotai dengiami augmenijos. Kadangi operatorius gali tiksliai išmatuoti žemès paviršių, kur augalija retesne, šiose vietose tikslinga naudoti papildomai stereodigitalizuotus aukščių taškus.

Kadangi stereofotogrametriniai matavimai Kaune nebuvo atlikti, SRM tikslumas tirtas, lyginant su didelio tikslumo SRM (ląstelès dydis $2 \times 2 \mathrm{~m}$ ), gautu iš 1:10 000 mastelio žemėlapio horizontalių. Kontrolei naudota 7100 aukščių taškų (4 lentelè). 
4 lentelè. Statistiniai SRM tikslumo parametrai

Table 4. Statistical accuracy parameters of DTM

\begin{tabular}{|l|c|}
\hline SRM statistiniai duomenys & $\begin{array}{c}\text { Gauta automatiniu } \\
\text { stereofotogrametriniu } \\
\text { metodu }\end{array}$ \\
\hline Kontrolinių taškų skaičius, vnt. & 7100 \\
\hline Vidutinis altitudžių skirtumas $\Delta h, \mathrm{~m}$ & $-2,94$ \\
\hline Standartinio nuokrypio i̇vertis $\sigma, \mathrm{m}$ & 6,23 \\
\hline $\begin{array}{l}\text { Didžiausias altitudžiu skirtumas } \\
\Delta h_{\max }, \mathrm{m}\end{array}$ & 26,56 \\
\hline
\end{tabular}

\section{Reljefo modelio, sudaryto stereofotogrametriniu} būdu, analizè

Stereofotogrametrinių matavimu privalumas galimybė išdéstyti taškus pagal poreiki. Stereodigitalizuodamas, priklausomai nuo reljefo situacijos, operatorius gali pasirinkti pradinių tašku išdèstymą taip, kad būtų atspindètos svarbiausios reljefo savybès. Be to, rankinis darbas leidžia išvengti augalijos ir antropogeninių objektų patekimo i sudaromą reljefo modeli. Metodo trūkumas tai, kad rankinis darbas reikalauja daug laiko sąnaudų, todèl jis nèra labai produktyvus ir, palyginti su kitais metodais, gana brangus.

Analizuodama taikytų metodų tikslumą straipsnio autorè ištyrè Vilniaus $2 \mathrm{~m}$ skiriamosios gebos skaitmeninio reljefo modelio fragmentą, sudarytą naudojant stereodigitalizuotus aukščiu taškus. Aukščiu taškai išmatuoti stereofotogrametriniu prietaisu A8. Matavimai atlikti $121,86 \mathrm{~km}^{2}$ plote Vilniaus teritorijoje. Skaitmeniniam reljefo modeliui sudaryti straipsnio autore pasirinko Šeškinès ozą.

Kadangi autorè norëjo sudaryti labai tikslų SRM, buvo atliktas papildomas stereodigitalizavimas, išmatuojant 5689 charakteringuosius vietovès tašku aukščius (5 pav.).

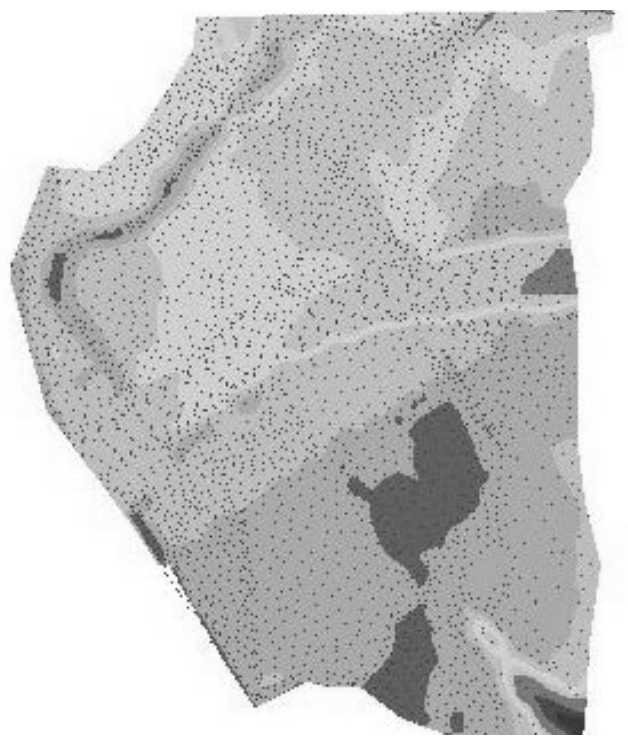

5 pav. Vilniaus dalies reljefo modelio kontrolinių tašku išsidèstymas

Fig 5. Distribution of segment Vilnius city DTM control points

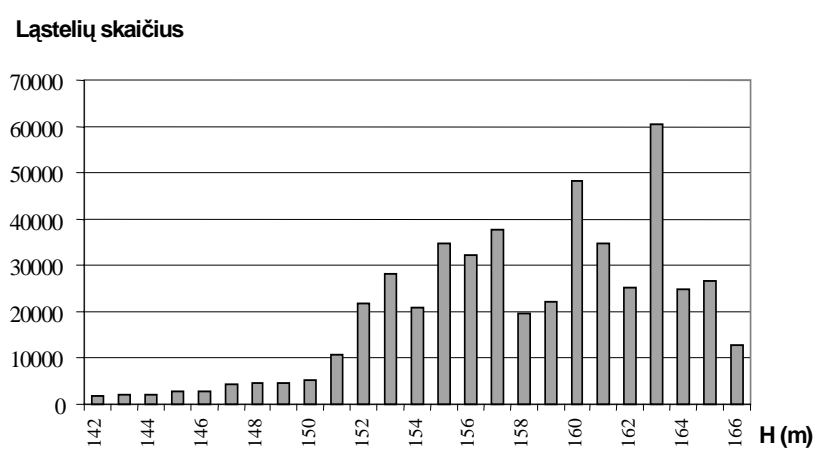

6 pav. SRM, sudaryto iš stereodigitalizuotų aukščių taškų, histograma

Fig 6. Histogram of digital terrain model created from stereodigitalized height points

Stereofotogrametriškai sudarytas SRM paviršius, skirtingai nei gautas interpoliuojant horizontales, kinta tolygiai (6 pav.).

Noredama vienareikšmiškai įvertinti iš skirtingu pradinių duomenų šaltinių gautų SRM tikslumą, straipsnio autorè $2 \times 2 \mathrm{~m}$ ląstelès dydžio SRM perskaičiavo i $50 \times 50 \mathrm{~m}$ (5 lentelè).

5 lentelè. $50 \times 50 \mathrm{~m}$ ląstelès dydžio SRM tikslumo duomenys

Table 5. Accuracy data of 50×50 m resolution DTM

\begin{tabular}{|l|c|}
\hline Statistiniai duomenys & $\begin{array}{c}\text { Šeškinės ozo teritorijoje } \\
\text { Vilniuje }\end{array}$ \\
\hline Kontrolinių taškų skaičius, vnt. & 3115 \\
\hline Vidutinis altitudžiu skirtumas $\Delta h, \mathrm{~m}$ & 0,74 \\
\hline Standartinio nuokrypio ivertis $\sigma, \mathrm{m}$ & 1,89 \\
\hline Didžiausias altitudžių skirtumas & 14,46 \\
$\Delta h_{\max }, \mathrm{m}$ & \\
\hline
\end{tabular}

Taip gautas SRM palygintas su stereofotogrametriškai išmatuotais aukščių taškais.

\section{Išvados}

1. Palyginus skaitmeninius reljefo modelius, sudarytus iš skirtingų pradinių duomenų, galima daryti išvadą, kad iš stereofotogrametrinių matavimo duomenu gautas SRM yra tiksliausias ir patikimiausias. Ištirtas SRM, sudaryto iš stereofotogrametriškai išmatuotų tašku, tikslumas $(\sigma=1,89 \mathrm{~m})$. SRM ląstelès dydis $(50 \times 50 \mathrm{~m})$ buvo suvienodintas su SRM modelio, gauto iš InSAR ir horizontaliu, duomenimis

2. Perspektyvu paviršius sudaryti automatiniu stereofotogrametriniu metodu, naudojant Leica ir panašias automatines darbo stotis, tačiau šiuo būdu gauti paviršiaus modeliai esti „užteršti“ antžeminių objektų. Būtina toliau paviršiaus modelị koreguoti, naudojant papildomus aukščiu duomenis urbanizuotose ir apželdintose teritorijose. Palyginus SRM, sudarytą automatiniu stereofotogrametriniu metodu, su SRM, sudarytu iš horizontalių, gautas standartinio nuokrypio ivertis $\sigma=6,23 \mathrm{~m}$.

3. Ištyrus automatiniu stereofotogrametriniu metodu sudaryto SRM nuolydžius, matyti, kad antžeminius 
objektus galima atskirti pagal paviršiaus nuolydžių reikšmes.

4. Iš horizontalių sudaryto SRM tyrimas parodè, kad didžiausi šio metodo trūkumai yra paviršiaus išsidèstymas „terasomis“ bei mažas teritorijų su staigiais reljefo pokyčiais reljefo modelio tikslumas. Šio tipo reljefo modelyje būtina papildomai koreguoti hidrografijos objektu kranto linijas. SRM tikslumas ištirtas imant 3115 kontrolinių taškų, gautas standartinio nuokrypio ivertis $\sigma=3,92 \mathrm{~m}$.

5. InSAR metodu sudaryto reljefo modelio tikslumas $-\sigma=4,57 \mathrm{~m}$. Atliktas tyrimas parodè, kad šiuo metodu sudarytas reljefo modelis yra „užterštas“ antžeminių objektų, paviršius lieka neišmatuotas staigių reljefo pokyčiu vietose. Lietuvos teritorijoje neišmatuoto paviršiaus plotas yra $53,56 \mathrm{~km}^{2}$.

\section{Literatūra}

1. Maune, D. F. Digital Elevation Model Technologies and Applications, the DEM Users Manual. American Society for Photogrammetry \& Remote Sensing. Bethesda, Maryland, 2001. $540 \mathrm{p}$.

2. Ritchie, J. C. Airborne laser altimeter measurements of landscape topography. Remote Sensing of the Environment, 53 (2), 1995, p. 91-96.

3. DeLoach, S. R.; Leonard, J. Making photogrammetric history. Professional Surveyor, 20 (4), 2000, p. 6, 8, 10.

4. Brock, J. C.; Wright, C. W.; Sallenger, A. H.; Krabill, W. B.; Swift, R. N. Basin and methods of NASA Airborne Topographic Mapper LiDAR surveys for coastal srudies. Journal of Coastal Research, 18 (1), 2002, p. 1-13.

5. Sandwell, D. T.; Smith, W. H. F. Bathymetric estimation: Except: Satellite Altimetry and Earth Sciences. In: Fu, L. L.; Cazenave, A. (eds.), A handbook of techniques and applications. New York, Academic Press; 2001, p. 441-457.
6. Small, D. Generation of Digital elevation Models Through Spaceborne SAR Interferometry. Department of Geography, Univ. Zurich, Remote Sensing Series, 1998. $150 \mathrm{p}$.

7. Gens, R. SAR interferometry - software, data format, and data quality. Photogrammetric Engineering and Remote Sensing, 65 (12), 1999, p. 1375-1378.

8. Carter, W. E.; Shrestha, R. L.; Tuell, G.; Bloomquist, D.; Sartori, M. Airborne laser swath mapping shines new light on Earth's topography. EOS Transactions, 82 (46), American Geophysical Union, 2001, p. 549-550, 555.

9. Kumetaitis, A. Investigation of Accuracy of Lithuanian Digital Elevation Model. Geodesy and Cartography (Geodezija ir kartografija), Vol XXVI, No 2. Vilnius: Technika, 2000, p. 79-83 (in Lithuanian).

10. Katczinski, R.; Ziobro, J. Digital aerial triangulation for DTM and ortophoto generation. Int. Arch. of Photogrammetry and Remote Sensing, 32 (4), Stuttgart; 1998, p. 281-283.

11. Katczinski, R. Digital aerial triangulation, DEM and ortophoto generation in IGIK. Geodesy and Cartography (Geodezija ir kartografija), Vol XXVI No 3, Vilnius: Technika, 2000, p. 105-110 (in Lithuanian).

Aušra KUMETAITIENE். Assistant. Vilnius Gediminas Technical University. Dept of Geodesy and Cadastre. Saulètekio al. 11, LT-10223 Vilnius-40, Lithuania $(\mathrm{Ph}+3705$ 2744703, Fax 3705 2744731). Chief specialist. Information Society Development Committee under the Government of the Republic of Lithuania. Electronic Services and Innovations Division. Gedimino pr. 56, LT-01110 Vilnius, Lithuania (Ph +370 5 2665187, Fax 3705 2665180),

e-mail: a.kumetaitiene@ivpk.lt.

A graduate of Vilnius Gediminas Technical University (BSc 1998, MSc 2000, Dr 2005). Courses in Norway (1997).

Research interests: digital elevation modelling, digital photogrammetry, GIS and multiparameter decision analysis. 